\title{
One Ever Feels His Twoness: Understanding the Service and Rhetoric of Barack Obama
}

\section{Marne L. Campbell}
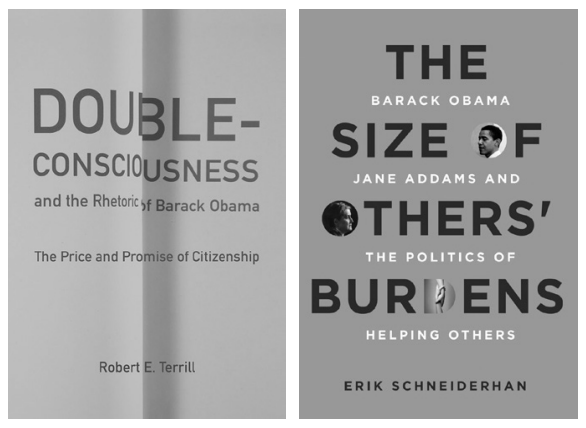

DOUBLE-CONSCIOUSNESS AND THE RHETORIC OF BARACK OBAMA: The Price and Promise of Citizenship. By Robert E. Terrill. Columbia: The University of South Carolina Press. 2015. THE SIZE OF OTHERS' BURDENS: Barack Obama, Jane Addams, and the Politics of Helping Others. By Erik Schneiderhan. Stanford, CA: Stanford University Press. 2015.

"It is a peculiar sensation, this double consciousness, this sense of always looking at one's self through the eyes of others, of measuring one's soul by the tape of the world that looks in on it in an amused contempt and pity."-W.E.B. Du Bois, The Souls of Black Folk, 1903.

W.E.B. Du Bois writes in The Souls of Black Folk (1903) that African Americans are born with a sort of second-sight for which to understand their position in the world, but particularly in American society. He understood, mostly by his 
own experiences as a black man working in the south at the beginning of the twentieth century, and as a trained scholar in history and sociology, that African Americans had the ability to see themselves not only as themselves, but also as outsiders (specifically white people) did. This occurs to him as a result of white people constantly asking him how it felt to be a problem.

Du Bois uses his first essay, "Of Our Spiritual Strivings" to explain the danger in maintaining a racial divide in the United States. He immediately draws the reader into the strivings of black American identity. At the heart of this is the peculiar position black people are in, which, in turn, gives them this double consciousness. Du Bois writes, "One ever feels his twoness, - an American, a Negro; two souls, two thoughts, two unreconciled strivings; two warring ideals in one dark body, whose dogged strength alone keeps it from being torn asunder" (Du Bois, p. 215). Historian David Levering Lewis points out that this was a profoundly radical idea at the time. While Du Bois did not invent double consciousness, his understanding of the concept put him a decade ahead of his time; he might actually have been a century ahead (Levering Lewis, p. 196).

$\mathrm{Du}$ Bois believed that African Americans were, "longing to attain selfconscious manhood, to merge his double self into a better and truer self" (Du Bois, p. 215), without compromising their black heritage. He explained, "he simply wishes to make it possible for a man to be both a Negro and an American, without being cursed and spit upon by his fellows, without having the doors of Opportunity closed in his face" (Du Bois, p. 215). This marks the start of Du Bois outlining the need for African Americans to gain full equality, which he outlines in his third chapter when he criticizes other black leaders, especially Booker T. Washington, for not pursuing an agenda that includes civic equality.

W.E.B. Du Bois was unwavering in his insistence of black equality. He understood that black people had been denied rights and, thereby, denied citizenship, insisting that black people demand the right to vote, civil equality, and education. He says, "The ballot, which before he had looked upon as a symbol of freedom, he now regarded as the chief means of gaining and perfecting the liberty which war had partially endowed him" (Du Bois, p. 217). For Du Bois, full equality under the law, and educational opportunities, were only the beginning.

He did this not only though his own teaching, but other pursuits like the American Negro Academy, which he co-founded in 1897 in Washington, DC. Its purpose was to promote academic study of African Americans, especially by publishing scholarly works in the field. He also began organizing and co-founded the Niagara Movement in 1905 and the NAACP in 1909, where he edited the organization's publication, The Crisis Magazine. Du Bois offers a good backdrop for understanding Barack Obama, and his rise to the highest political position in America.

Understanding Du Bois will also allow us to better frame Barack Obama's rhetoric, his identity, and his service. Both Robert E. Terrell and Erik Schneiderhan offer new ways of understanding Obama around these ideas. Although different approaches, both studies pay close attention to Obama's identity as 
duality. For Terrell, it can be found in his rhetoric as well as his biracial heritage. Terrell notes that race and citizenship in America are inextricably linked, the latter dependent upon the former.

Schneiderhan also emphasized Obama's biracial parentage and saw Obama's duality in his transition from a community organizer in Chicago to a national political figure. Schneiderhan also compares the life and work of Jane Addams to Obama's to make a hundred year comparison between two people with dual identities who transitioned into politics, which also caused them to make choices that could have compromised their identities. This essay, therefore, will focus on the ways in which these scholars present their understandings of how Obama's identity was shaped by his twoness as well as how he used that twoness to shape his rise to the presidency of the United States of America.

Robert E. Terrell argues that the fundamental necessity of rhetoric to democracy depends on dualities, and uses W.E.B. Du Bois' "double consciousness" as a lens through which one might understand race and the black experience in America, particularly during the lowest point in African American history often referred to as the Nadir (Terrell, p. xi). For him, the person who best exemplifies this is Barack Obama. Initially, he considered a collection of rhetorical situations, but as he was doing so, the then-Senator Obama became the central focus of the Democratic Party's primary election. Terrell saw him as, "a sort of icon of duality, both a speaking embodiment of a doubled attitude and an idealized democratic citizen" (Terrell, p. xii). Terrell combed through speeches of Obama's before settling on those he chose for this book, noting that they appeared to be "doubled tropes" which he saw in Du Bois' idea of double consciousness (Terrell, p. xiii).

Terrell introduces the term, "democratic double-consciousness to refer specifically to the manifestations of duality as a resource for rhetorical invention in a democratic context" (Terrell, p. xiii). To do so, Terrell chose a number of speeches Obama gave between 2008 and 2014. "A More Perfect Union" exemplifies Obama's thoughts on race in America in 2008. The speech was given at a critical point in the primary season as Obama was criticized for attending a black radical church. While most (non-black) people are unfamiliar with the black church, Obama's was seen as unpatriotic and radical because his pastor Jeremiah Wright's message included the words, "God Damn America!" This incited both Republicans and Democrats to call for an explanation as well as for Obama to denounce his pastor of 20 years. The consequences for him if he chose not to were too great not to distance himself from the church. This event forced Obama to do something he had not throughout most of the primaries - address the issue of race in front of the entire country.

Obama's speech, "A More Perfect Union," was his official statement to distance himself from the Reverend Wright, and he did so by "lifting the veil" Du Bois described in Souls to explain the black experience to white people. Du Bois explained that African Americans are, "born with a veil, and gifted with secondsight in this American world, - - a world that yields him no true self-consciousness, but only lets him see himself through the revelation of the other world" (Du 
Bois, p. 215). Obama clearly believed the Jeremiah Wright sermon was enough for him to lift the veil and let white people in. Terrell notes that Obama told his campaign manager David Plouffe that he had been waiting to give this speech for thirty years, or, his entire adult life (Terrell, p. 58). Obama made his speech on March 18, 2008, just seven and a half months before the election.

Terrell views Obama's speech in terms of rhetoric - as an "inventional resource for citizenship" (Terrell, p. 58-59). He found this speech particularly important in understanding the veil, double consciousness, and race. He says the speech, "can be translated into a democratic double-consciousness that fosters the invention of discourse about race and, in turn, the invention of talk among citizens" (Terrell, p. 59). This speech, therefore, would open the door not only for white people to understand black people's experiences and perspectives, but also for white people to understand Obama in ways they had not known him-as an African and an American. This is also very important because Du Bois had talked a lot about citizenship and civic equality. He knew that black people had to have the same rights and opportunities as white citizens; and, Barack Obama's speech resembled Du Bois' essay.

The speech itself was well received, and is often the standard for which Obama is held to when he addresses the American people, particularly given the myriad of racial incidents that have occurred across the country in the past few years such as protests in response to the deaths of several black people at the hands of police, vigilante individuals, and white supremacists like Dylan Roof who killed nine people, including the pastor of the historic Mother Emmanuel A.M.E. church in Charleston, South Carolina on June 17, 2015.

Perhaps Obama's eulogy of Reverend Clementa Pinkney comes close, particularly when he again lifts the veil, so white people would understand the history and significance of the African American church. He said, "The church has been the center of African American life ... That's what happens in church. That's what the black church means - our beating heart, the place where our dignity as a people is inviolate" (The Washington Post, 06/26/2015). Until this moment, pundits and political commentators criticized President Obama for not making speeches like the one he gave in response to the Reverend Wright situation, in terms of race. But before this moment, the majority of Obama's speeches did not directly address race, although, Terrell argues, they were inherently about race.

Terrell notes that "A More Perfect Union" was engendered by a rare rhetorical situation that allowed Obama to directly address race relations in America. He also recognizes that Obama shifts how he talks to audiences who are predominantly black versus predominantly white. This exemplifies the ways in which Terrell sees democratic double consciousness deeply rooted in racial frictions. To illustrate this point, he notes how Obama sees himself as an extension of the civil rights movement of the 1960s. By invoking Martin Luther King Jr., and avoiding controversial figures (like Malcolm X, Stokely Carmichael, Angela Davis and others), Obama, "attenuates much of the alienation that prompts double 
consciousness, in Du Bois's original formation" (Terrell, p. 101). It was when Obama strayed from this paradigm that he faced severe backlash.

Harvard Professor Henry Louis Gates was arrested going into his Cambridge home after a passerby saw him struggling to open his jammed front door. When asked about the incident, President Obama said that the officer, Sergeant James Crowley "acted stupidly" (Terrell, p. 122). He faced a significant backlash for those comments, which resulted in his inviting both Gates and the officer to the White House for what has been called a "beer summit;" but those paled in comparison to the reaction to comments he made in 2012.

On February 26, a teenage boy named Trayvon Martin was walking back from a 7-Eleven convenience store when he encountered George Zimmerman, a man who lived in the same development as Trayvon's father, Tracy. A fight occurred, and before long, Trayvon laid dead in the grass between two rows of condominiums. Zimmerman alleged that Martin attacked him, and he was merely standing his ground in accordance with Florida's “castle laws." Weeks later, people began protesting, demanding Zimmerman's arrest. Soon, President Obama was asked to comment on the situation. He said that if he had a son, he would look like Trayvon. The backlash was swift. President Obama was severely criticized and called divisive, and was accused of playing the race card amongst other things. Although several racially charged incidents have occurred since then, Obama has been much more selective and reserved when speaking about race. This is precisely Terrell's point, however, that even when he is not directly addressing racial situations, race may still be a focal point. But more significantly, that racial speech has limitations that are often quite severe (Terrell, p. 91-93).

Terell considers three of Obama's speeches during his first term that are not about race in order to explain how he negotiates his way in and outside of the veil. Healthcare reform, accepting the Nobel Peace Prize, and the dedication of the John Brown Memorial are examples used to show that Obama can address race indirectly, and Terrell argues that this also exemplifies democratic double consciousness. Each of these speeches included predominantly white audiences. Obama does not center any of these speeches on race, but the discussions building up to them frequently did - often with a strong dose of criticism. Obama linked these speeches to the larger need for civic responsibility, however, and because race and citizenship are relational, Obama is able to get around directly talking about race. This is how he negotiates the veil, which allows Obama to address race via democratic double consciousness and, in turn, stretches discourse beyond the confines of race (Terrell, p. 134).

Terrell sees aspects of Obama's discourse as providing resources for which citizens can recognize one another as citizens being addressed. This, then, enables him to discuss race and influence racial discussions amongst citizens without directly talking about race or racial situations. Terrell notes that his "rhetoric is actually steeped in African American rhetoric tradition" (Terrell, p. 154). Since race is such a difficult topic to talk about, it places limitations on Obama's speeches. Like several other commentators, Terrell believes that Obama should talk more 
about race in the way he did in his "A More Perfect Union" speech particularly because he sees it as instructive for engaging citizens' active discussions of race. Obama's rhetoric is not the only example of his double consciousness. His service is illustrative of this twoness, as Sociologist Erik Schneiderhan notes.

Erik Schneiderhan's book The Size of Others' Burdens considers Jane Addams and Barack Obama's roles in public service. Here, he is primarily concerned with how Americans act when facing competing social pressures and what happens once people get involved in politics and have to work with elites. Using Addams and Obama, Schneiderhan makes suggestions for confronting what Economist Gunnar Myrdal framed as the American Dilemma (1944). He contends, "The conflicting social demands of individualism and community assistance comprises a challenge that many face-it's the American Dilemma" (Schneiderhan, p. 6). Both Addams and Obama had to confront this problem.

On the surface, Jane Addams and Barack Obama could not be further apartshe was an elite white woman who inherited a large sum of money from her father, and he is an upwardly mobile middle class black (some prefer biracial) man who was raised by his single (white) mother and grandparents. Her work occurred at the turn of the twentieth century while his was at the turn of the twenty-first. But what they have in common is Chicago, community organizing, and politics. Addams was always aware that she was privileged and how that dictated her position in society. Conversely, Obama was exposed to several situations, both in America and abroad, where people were in great need of resources. Both were influenced by their parents to help.

Addams believed in helping those less fortunate, and the opportunity presented itself in 1871, when a fire burned through the city of Chicago for two days. Killing over 300 people, the fire burned almost two thousand structures, and left thousands of people homeless. The city was without proper resources to handle a disaster of this level, and very little social welfare to help. Those that did exist placed several requirements for people to get help, such as the church and the more elite members of the Social Gospel movement. Using mostly her own money, Addams established Hull House as a solution that was neither relief nor a charity with very few and, more importantly, very affordable strings attached. Hull House was innovative, and became a central organization for helping those less fortunate.

In determining how to reach people in need, Addams mapped out a plan to get people into the home. With very few places available that were similar, Addams determined it best to recruit people through their children. Since they needed to be cared for while their mothers worked, Hull House offered hot lunches. They also started a daycare so that working moms had a safe place for their children while they worked. In doing so, Hull House attracted adults. Addams began holding meetings at Hull House to discuss social problems and soon they established the Social Science Club, which was mostly attended by male adults. These meetings led to addressing political educational concerns. Hull House also attracted im- 
migrants and people of color. Schneiderhan notes that it was distinctive in that way. In doing so, Hull House could expand to include other services.

Jane Addams saw other needs that poor people, black people, and immigrants faced, and addressed those needs by building public baths and providing showers for people to cleanse as well as a playground for children. She also founded the "Jane Club" which was a boarding house for female members who could rent rooms for $\$ 3$ a week. This money was helping Addams expand her services, although it was far more costly than she initially thought.

Addams found the solution to her financial burden of keeping her service ventures afloat. Initially, she wanted to turn her organization into a charity, but found the business model unfavorable. She settled on creating a parallel organization focused on charity, which she called the Chicago Bureau of Charities. This organization's platform differed from Hull House in that its model, among other things, was to "rid the streets of tramps and beggars. .." (Schneiderhan, p. 77). As with other charities, the Chicago Bureau was designed to help "upstanding" people, thereby placing conditions on those in need. She turned to politics as a way of solving this problem, but this involvement only exposed her to the cost and consequences of political favors. Soon, Addams realized the price of politics was high. While Addams significantly impacted how we help others, her brief role in politics exposed her to the grim reality of power and privilege in America. Barack Obama, however, utilized his role as a community organizer to launch his political career.

Many biographers highlight Obama's dual identity as a result of being biracial. Indeed, Obama's identity was shaped over time, but really honed during his young adult years. But this is not uncommon - people learn about their own sexuality, religion, and political leanings during these years. Obama's own writings stress his racial background and how he came to understand himself as a black man even given his biracial heritage, multiracial and multiethnic upbringing, and his experiences of often being one of the only people of African descent in racially and ethnically homogeneous surroundings. But there are other clues that cannot be overlooked, and some of them can be found in his decisions about community service. As opposed to Addams, Obama's service was specific to the black community as a participant of that community.

Schneiderhan found in Obama's writings a belief that communities were not given, but made, and that this was especially true for African Americans. Schneiderhan notes, "Inherent in the American civil rights movement that had been so formative in Obama's thinking was the notion that, 'through shared sacrifice' people could create a robust community that worked for everyone, regardless of color" (Schneiderhan, p. 108). This was quite different from the way Addams envisioned service, but it is also reminiscent of Obama's understanding himself as a member of a particular community (in this case, the black community), rather than an outsider or a mere observer.

Although Scheiderhan's focus is not specifically on Obama's double consciousness, one cannot overlook the implicit ways in which it plays out through 
Obama's service and rise to the presidency. For example, in chapter four "Wake Up! It's Morning in America!" Schneiderhan described Obama's upbringing, noting his education in elite schools from high school to college where he read Alexis de Tocqueville and learned about community building and democracy at Occidental College in Los Angeles (Schneiderhan, p. 114). It was precisely during these years, however, that Obama began looking for his calling that would eventually lead to service. Schneiderhan notes, "There appears to have been some sort of interaction, in Obama's self-construction, between the idea of creating community and fostering an entire ethic of compassion and humanism" (Schneiderhan, p. 114). His education and his mother's influence came together at this moment, and Obama turned to politics through public speaking.

Obama had always thought of himself as an extension of Martin Luther King, Jr. and the civil rights movement of the 1960s. This is an important distinction to make because in embracing the southern, middle-class movement, he distanced himself from the more "radical" black power movement that extended civil rights into the 1970s. Much of the earlier movement was organized in the church, drawing its leadership largely from black preachers who were amongst the most respected people in their communities. So when he spoke publicly, Obama drew on the oratorical style of black preachers without having much experience in the black church. This helped Obama when he began working in the black community in Chicago and most certainly helped when he ran for president.

Schneiderhan highlights Obama's double consciousness as essential to his community service in Chicago. He says Obama, "had long-since cultivated his 'twoness' - a dual persona that put him as much at ease in the poor neighborhoods of Chicago as in the halls of Columbia" (Schneiderhan, p. 134). His upbringing helped him hone that twoness and, while Schneiderhan understands this as an insider/outsider issue, one might see it in terms of veil/counter veil. Obama was approachable and could talk to different people in different situations. More importantly, he listened to the people, and that made community organizing much easier while facing challenges. According to Scheiderhan, "His own relative material success was apparent, but his responsibilities were not. His privilege was likely an uncomfortable mantle. His twoness was again a burden" (Schneiderhan, p. 156). In order to help the black community in Chicago, Obama needed the help of black politicians to completely be accepted; eventually he would earn their support.

Barack Obama targeted disenfranchised African Americans first, as local politicians stressed the need for massive political campaigns. Together, they registered over 150,000 people to vote, which in turn placed Obama at the center of local politics in the early 1990s (Schneiderhan, p. 167). This also solidified Obama's transition from political outsider to insider. For Obama, community organizing was what came naturally, but he also knew that he would get more directly involved in politics by eventually running for public office. Schneiderhan credits Obama's double consciousness for this. He states, "Drawing on the twoness of his identity and his education and privilege, he envisioned and then 
constructed a unique path forward as a community organizer in Chicago" and, "Obama's life thus far has been one of adjustment and coexistence, of finding a balance in the face of his dilemmas" (Schneiderhan, p. 177). In all, Obama has had to operate in and out of the veil in order to negotiate his way from community organizer to president of the United States of America.

Both of these texts draw on examples of how Barack Obama has been shaped by a dual consciousness. Whereas Terrell considers Obama's rhetorical style to reveal certain things about his identity, Schneiderhan explores Obama's duality as a way of explaining his ascendancy to the highest office in the country. Though very different in content, these two sources can provide a different way of understanding both the service and rhetoric of Barack Obama when read together.

Even Obama liked to think of himself as an extension of the work done by Martin Luther King, Jr. and other civil rights leaders of the 1960s, but he actually should be understood as an extension or embodiment of W.E.B. Du Bois, particularly as he explains double consciousness and the veil. It would be easy to consider Obama's works as an extension of civil rights with his brilliant oratory, voter registration, and community organization. True, securing the right to vote and attaining civil and educational equality is what so many African Americans hoped for. But that was also the platform Du Bois outlined in The Souls of Black Folk. In his third essay, "Of Mr. Booker T. Washington and Others," Du Bois notes that these should be the goals for African Americans, while criticizing black leaders for not being fully committed to the platform. He closes the chapter saying, "By every civilized and peaceful method we must strive for the rights which the world accords to men, clinging unwaveringly to those great words which the sons of Fathers would fain forget: 'We hold these truths to be self evident: That all men are created equal; that they are endowed by their Creator with certain unalienable rights; that among these are life, liberty, and the pursuit of happiness'." (Du Bois, p. 252). These are the ideas Obama embodies. And, these ideas highlight both texts' theses.

As Terrell argues, "This is perhaps especially true for a book like this one, in which citizenship is construed as a discursive practice, because our difficult racial past has a profound effect on the way we talk about citizenship" (Terrell, p. 17). In The Souls of Black Folk, Du Bois connects race and citizenship by illustrating for his audience, "the strange meaning of being black here at the dawning of the Twentieth Century" (Du Bois, "Forethought" p. 209). He tells his audience that he is going to move within and without the veil in order for them to understand race relations in America. This is precisely how Terrell reads Obama's "A More Perfect Union" speech. He sees this moment as the moment Obama lifted the veil to reveal some very important things about black America that white people either may not have known or did not want to know. Obama does this again during his eulogy of the Reverend Clementa Pinkney who was gunned down at a bible study in 2015.

Erik Schneiderhan does not focus his study on double consciousness, but it is a current that runs throughout his book. He sees Obama as a man of dualities, 


\section{Marne L. Campbell}

based mostly on his biracial heritage, but also because he was constantly shifting from one racially and/or ethnically homogenous place to another. But once he became a young adult, Obama came into his own and learned the importance of the veil that $\mathrm{Du}$ Bois described. Obama, understanding what it means to be black in America, traveled frequently within and without the veil. Schneiderhan illustrates how Obama's twoness allowed him to step into a community he was not a part of to hone his community service experience while jumpstarting his political career.

Although Obama sees himself as an extension of civil rights, he is also an extension of W.E.B. Du Bois, and there are some comparisons to be made. Both had mixed-race backgrounds, although Obama was more directly linked to his white heritage than Du Bois because of his white mother. Both were privileged in certain ways. Both attended Harvard University for their postgraduate education - Du Bois for a Ph.D. and Obama for a J.D., and both had very clear ideas that African Americans needed to gain full and equal citizenship.

At the end of The Souls of Black Folk, Du Bois challenges the white reader. He says, "Your country? How came it yours? Before the Pilgrims landed we were here. Here we have brought our three gifts and mingled them with yours: the gift of story and song - soft, stirring melody in an ill-harmonized and unmelodious land" (Du Bois, p. 386). The other two gifts were sweat and brawn that helped clear land that "lay the foundations of this vast economic empire" and "the gift of the Spirit" (Du Bois, p. 386-387). Du Bois offers white readers the opportunity to correct the past, and challenges them to acknowledge the contributions African Americans have made. "Our song, our toil, our cheer, and warning have been given to this nation in blood-brotherhood" he says (Du Bois, p. 387). He then asks white people whether America would be what it is without black people.

$\mathrm{Du}$ Bois offers a thought of hope- - "If somewhere in this whirl and chaos of things there dwells the Eternal Good, pitiful yet masterful, then anon in His good time America shall rend the Veil and the prisoned shall go free" (Du Bois, p. 387). As David Levering Lewis noted, Du Bois was well ahead of his generation. While Obama has yet to go further in his approach to race relations in America at the beginning of the twenty-first century, one still recognizes the similarities and influence of Du Bois. Obama has reminded us about double consciousness and the veil, and he has operated in and out of it throughout his political career as well as his service to his community. One only hopes to see Obama challenge America on race in similar ways as his predecessor. 